\title{
STPAHYLOCOCCUS AUREUS BIOFILMS ON CENTRAL VENOUS HAEMODIALYSIS CATHETERS
}

\author{
Elisabeth Eyko Aoki ${ }^{1}$; Antonio Carlos Pizzolitto ${ }^{1}$; Lourdes Botelho Garcia ${ }^{2}$; Elisabeth Loshchagin Pizzolitto ${ }^{1 *}$ \\ ${ }^{1}$ Universidade Estadual Paulista, Faculdade de Ciências Farmacêuticas, Araraquara, SP, Brasil, ${ }^{2}$ Universidade Estadual de \\ Maringá, Maringá, PR, Brasil
}

Submitted: December 12, 2004; Returned to authors for corrections: September 27, 2005; Approved: November 07, 2005

\begin{abstract}
Biofilm bacterial infections are common in patients undergoing treatment with haemodialysis. This study involved 16 patients ( 7 males, 9 females; ages from 22 to 81 with an average age of 50) who had had a total of 25 temporary haemodialysis polyurethane catheter insertions into the subclavian vein ( 22 dual-lumen and 3 triple-lumen). The catheters remained in place from 3 to 91 days, on an average of 47 days. The reasons for catheter removal were: bad functioning (44\%), suspicion of catheter-related infection (20\%), availability of permanent access (16\%), accidental removal (12\%), signs and symptoms of infection at the site of catheter insertion (4\%), and exogenous contamination (4\%). Positive tip cultures were observed on seven of the catheters (28\%), showing three positive blood cultures. The Staphylococcus aureus were identified in $12 \%$ of the blood cultures and isolated from one of the hubs, and biofilms were observed on all catheter tips. The S. aureus retrieved from both blood and catheters (tips and hubs) were resistant to penicillin and susceptible to azithromycin, ciprofloxacin, clindamycin, chloramphenicol, gentamicin, oxacillin, rifampin, sulfamethoxazole, tetracycline, and vancomycin. The $S$. aureus strains isolated from both blood and catheters (tips and hubs) were considered to be identical based on antibiotic susceptibility patterns and genetic similarity assessed using an automated ribotyping system.
\end{abstract}

Key words: biofilm, catheter in haemodialysis, central venous catheter, catheter-related infections

\section{INTRODUCTION}

Staphylococcal infections, particularly those caused by Staphylococcus aureus, produce substancial morbidity and mortality in haemodialysis patients (2). Prosthetic devices provide sites for staphylococci colonization. The importance of prosthetic material as a determinant of infection is reflected in the variable rates of sepsis associated with different types of vascular haemodialysis access (36). The use of central venous haemodialysis polymer-made catheters, is a risk factor for infections, and is a leading cause of $S$. aureus bacteremia (31). The pathogenesis of catheter-related infections is multifactorial, and is a crucial step in the adherence of $S$. aureus to the polymer surface (2). The microorganisms on catheter surfaces are in two forms: the sessile form, whereby organisms are embedded in a biofilm (38), believed to be responsible for the increased resistance to antibiotics $(13,21)$, and the planktonic free-floating form, in which the organisms disseminate $(13,24,38)$. Studies involving transmission and scanning electron microscopy have shown that almost all indwelling vascular catheters, even those for which quantitative catheter cultures are negative, are colonized by microorganisms, usually embedded in a biofilm layer (38). The aim of the present study was to detect bacterial biofilms on central venous haemodialysis catheters and hubs, using scanning electron microscopy, as well as semi and quantitative culture methods.

\section{MATERIALS AND METHODS}

The present study was approved by a committee of ethics and involved 16 patients ( 7 males, 9 females; ages from 22 to 81 years, average age of 50). Studies were carried out from January

*Corresponding Author. Mailing address: Faculdade de Ciências Farmacêuticas, Campus de Araraquara, CRD-NAC, Setor de Microbiologia Clínica. Rua Expedicionários do Brasil, 1621. 14801-360. E-mail: pizzolel@fcfar.unesp.br 
to October, 2002. A total of 25 polyurethane haemodialysis catheter tips were collected aseptically from patients who had had dialysis catheters inserted into the subclavian vein for periods of 3 to 91 days (average of 47 days). Catheters were removed when no longer required, or when there was a suspicion of complication.

The catheters were removed aseptically, and a $5-\mathrm{cm}$ segment of the tips was cultured semiquantitatively, by rolling them back and forth across the surface at least four times, on a 5\% sheepblood agar plate. Colonies were counted after 48 to $72 \mathrm{~h}$ of incubation at $35^{\circ} \mathrm{C}(26)$. The criterion for positivity was when more than 15 colony-forming units were isolated.

Catheter cultures were performed by a modified quantitative method described by Cleri et al. (7), and carried out by flushing the catheter lumen with $4 \mathrm{~mL}$ of Trypticase Soy Broth (TSB; BBL Microbiology Systems, Cockeysville, Md.), which was then diluted 10 -fold, and each dilution $(0.1 \mathrm{~mL})$ was streaked onto $5 \%$ sheep-blood agar plates. The agar plates were incubated at $37^{\circ} \mathrm{C}$ for 72 hours. The culture was considered positive if more than 1,000 colony-forming units were isolated.

Cultures of the catheter hubs were obtained by brushing the inner surfaces with a sterilized conic brush (19), followed by immersion of the brush into Mueller Hinton broth $(2 \mathrm{~mL})$, in order to determine the presence or absence of microorganisms. Cultures of blood were made and compared with semi- and quantitative cultures from the catheter tips. Scanning electron microscopy was used to analyze both the catheters tips and conic brushes (37). Blood samples were drawn from a peripheral vein for culture in an automated system (BACTEC 9050 with BACTE PLUS bottles). Positive specimens were transferred onto MacConkey, Blood, and Chocolate agars. The strains isolated were identified by using the same method as Murray et al. (30). Antibiotic susceptibility studies were performed using disk diffusion on agar as described by Bauer et al. (3) and S. aureus strains were tested for susceptibility to azithromycin, ciprofloxacin, clindamycin, chloramphenicol, gentamicin, oxacillin, penicillin, rifampin, sulfamethoxazole, tetracycline and vancomycin (Cecon, São Paulo, SP, Brasil) as recommended by NCCLS-M100-S12 (34). The Staphylococcus aureus isolated from blood, catheter tips and hub were ribotyped using the RiboPrinter $^{\circledR}$ Microbial Characterization System (Qualicon, Wilmington, Del., EUA) as described by Bruce (5) is automated process includes bacterial cell lysis, and cleavage of the DNA using the restriction enzyme SmaI, size separation using gel electrophoresis, and modified Southern blotting. The DNA fragments were hybridized with a labelled DNA probe (derived from a Staphylococcus aureus rRNA 16S), and the bands detected using a chemiluminescent agent. The images were photographed and stored in the system computer. Each lane of sample data was normalized to a standard marker set and band intensity, and then compared with reference patterns. Similarity coefficients were calculated based on both position and relative band weight $(17,22)$.

\section{RESULTS AND DISCUSSION}

Biofilms on central venous catheters have routinely been detected by a semiquatitative procedure, in which the quantification of the biofilm on the catheter tip is dependent upon the number of organisms that are recovered by contact on the agar surface (13). A number of investigators have used this procedure to quantify biofilms and determine the relationship between biofilm formation and bloodstream infection (1). However, this technique will not detect organisms on the inner lumen of the catheter and is unable to detect more than 1,000 CFU per tip (13). Cleri et al. (7) used quantitative broth culture of the inside of intradermal and intravascular segments by flushing and plating serial broth dilutions. They found that the growth of more than 1,000 CFU from a segment was associated with bacteremia.

In our study, positive tip semiquantitative cultures were obtained from 10 catheteres $(40 \%)$, data consistent with findings of Almirall et al. (1), 55\%. The quantitative procedure showed that 4 catheters $(16 \%)$ had $10^{3}$ or more CFUs per milliliter, while cultures were negative in 18 (72\%). Focusing on catheters cultured by both methods (roll plate and flushing), 3 concomitant positive blood cultures were obtained. As reported by others authors, the Cleri (7) and Maki (26) methods have been compared and have produced comparable results $(24,42)$, but the semiquantitative procedure proved to be easier and faster (6).

Studies have shown that the more organisms present on the catheter, particularly those embedded in the biofilm layer, the higher the likelihood of infection $(25,41)$. In our research, the causative microorganisms of the catheter-related infections and cases with concomitant bacteremia are listed in the Table 1.

Our data showed that the hub culture was positive only in one patient with bacteremia. A total of 53 catheter hub cultures were taken during the period of study. Of these, 4 (7.5\%) yielded 6 isolates: S. aureus, 1; Stenotrophomonas maltophilia, 2; Enterobacter aerogenes, 1; Enterobacter sakazaki, 1; Chryseobacterium meningosepticum, 1. Nichols and Raad (33) reported that the pathogens associated with hub contamination

Table 1. Causative microorganisms of catheter-related infection, their incidence and concomitant cases of bacteremia.

\begin{tabular}{lcc}
\hline \multicolumn{1}{c}{ Microorganisms } & No $^{\text {of Cases }}$ & Bacteremia \\
\hline Staphylococcus aureus & 3 & 3 \\
Diphteroid rods & 3 & 0 \\
Staphylococcus warneri & 2 & 0 \\
Staphylococcus epidermidis & 1 & 0 \\
Stenotrophomonas maltophilia & 1 & 0 \\
\hline Total & 10 & 3 \\
\hline
\end{tabular}


in their study were Acinetobacter sp, Candida albicans, Candida parapsilosis, Pseudomonas aeruginosa and Stenotrophomonas maltophilia. They noted that hub contamination occurs more often in catheters in place for longer than 30 days, because of more frequent manipulations. In our study, catheters were in place for no longer than 3 days, and the positive $S$. aureus culture from the hub occurred in only one case, and this was obtained on the same day as the blood sample from which $S$. aureus was cultured (Table 2). Hub colonization plays an important role in catheter-related bloodstream infection $(23,40,42)$. The detection of hub colonization with the same microorganism recovered from the blood shows that hub contamination is important in the pathogenesis of catheter related infections (40).

Our results also showed that bacteremia caused by $S$. aureus with the same antibiotic sensivity pattern was observed in 3 patients (30\%). None of the S. aureus strains were methicillin resistant, and all strains $(100 \%)$ were resistant to penicillin, contrary to other studies, such as, Nielsen et al. (32), who reported $86 \%$ penicillin resistant S. aureus. Marr et al. (29) found that $25 \%$ of $S$. aureus were characterized as methicillin resistant, and Kairatis and Gottlieb (20) reported $20-40 \%$ of methicillin resistant $S$. aureus associated to hemodialysis catheter-related bacteremia.

Data from the automated ribotyping system used to type $S$. aureus showed that the patterns of groups obtained were similar for all strains examined (Table 3 ). The same ribogroup from blood isolates was also recovered from the catheter tip in three cases, and from the hub in one case (Table 2-3).

As reported by Hung et al. (18) and Nielsen et al. (32), the microorganisms most frequently isolated during catheterassociated bacteremia are S. aureus and S. epidermidis. They reach the bloodstream of the patients via the catheter tunnel or via the catheter hub. The attachment of the bacteria to the catheter surface depends on the interactions, first, of the host,

Table 2. Catheter tips and hubs cultures compared with blood isolates and .

\begin{tabular}{|c|c|c|c|c|c|c|}
\hline \multirow{3}{*}{$\begin{array}{c}\text { Catheters } \\
\text { Number }\end{array}$} & \multicolumn{6}{|c|}{ Cultures } \\
\hline & \multirow[t]{2}{*}{ Blood } & \multicolumn{2}{|c|}{ Catheter culture } & \multicolumn{3}{|c|}{ Hubs } \\
\hline & & SQC & QC & H1 & $\mathrm{H} 2$ & $\mathrm{H} 3$ \\
\hline 1 & S. aureus & $\begin{array}{l}\text { S. aureus } \\
\left({ }^{3} 15\right)\end{array}$ & $\begin{array}{l}\text { S. aureus } \\
\left(<10^{3}\right)\end{array}$ & $(-)$ & $(-)$ & $(-)$ \\
\hline 5 & S. aureus & $\begin{array}{c}\text { S. aureus } \\
\left({ }^{\beta} 15\right)\end{array}$ & $\begin{array}{c}\text { S. aureus } \\
\quad\left(>10^{3}\right)\end{array}$ & S. aureus & $(-)$ & $(-)$ \\
\hline 7 & S. aureus & $\begin{array}{l}\text { S. aureus } \\
\left({ }^{\beta} 15\right)\end{array}$ & $\begin{array}{c}\text { S. aureus } \\
\left.\qquad>10^{3}\right)\end{array}$ & $(-)$ & $(-)$ & $(-)$ \\
\hline
\end{tabular}

$\mathrm{SQC}=$ semiquantitative culture; $\mathrm{QC}=$ quantitative culture.
Table 3. Distribution of the $S$. aureus ribogroups among isolates from blood and catheters.

\begin{tabular}{clcc}
\hline Patients & Isolation site & Microorganisms & Ribogroup \\
\hline 1 & Blood & S. aureus & 222-108-S-2 \\
& Catheter tip & S. aureus & $222-108-S-3$ \\
5 & Blood & S. aureus & $222-108-S-4$ \\
& Catheter tip & S. aureus & $222-108-S-4$ \\
& Hub & S. aureus & $222-108-S-6$ \\
7 & Blood & S. aureus & $222-109-S-4$ \\
& Catheter tip & S. aureus & $222-109-S-4$ \\
\hline
\end{tabular}

which reacts to the catheter as a foreign body by forming a thrombin rich in fibrin and fibronectin, two substances that are tightly adhered to by $S$. aureus (39). Secondly, the microbial factors consists of the production of fibrous glycocalyx, also known as extracellular slime, that constitutes the matrix of the biofilm $(8,9)$ The third factor that plays a role in the attachment process is the catheter material. As reported by Pascual (35), the adherence of different microorganisms to, and their survival in catheters is promoted not only by bacterial factors, but also by bacterium-device interations. Several investigators have shown, for example, that $S$. aureus adhere better to polyvinylchloride catheters than to Teflon catheters (39). In our research, we studied dual and triple-lumen catheters made of polyurethane. As reported by Butterly and Schwab (4), the dual-lumen catheters are usually made of polyurethane or polyvinyl and are suitable for short-term use of a few days to a few weeks.

Scanning electron microscopy has been used in the research setting to evaluate catheter colonization (12). In the current study, electron microscopic examinations of catheter tips demonstrated endoluminal and extraluminal biofilms on all catheter-related infections. Fig. 1 shows the $S$. aureus biofilm on a central venous catheter, as confirmed by the presence of both bacterial cells and extracellular polymeric substances. Our data are consistent with others, such as Donlan et al. (14), who examined by scanning electron microscopy needleless conectors attached to central venous catheters shown to develop microbial contamination as biofilms. Marrie and Costerton (27) and Marrie et al. (28) related that Staphylococcus aureus biofilm has been observed on surfaces ranging from intravascular catheters to pacemaker leads. Cunningham and Cheesbrough (10) noted that Staphylococcus aureus is capable of biofilm formation, which increases its persistence and boosts its levels of antimicrobial resistance.

In the current study, all Stahylococcus aureus isolates were available for antimicrobial susceptibility tests and 


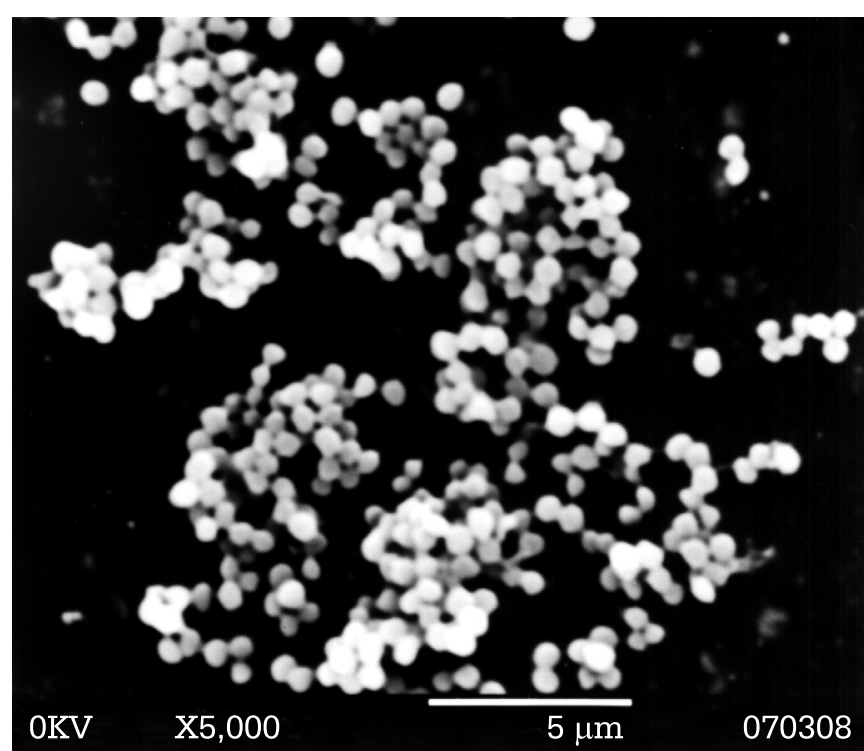

Figure 1. Scanning electron microscopic image of the internal surface of a central venous polyurethane catheter segment from a patient with catheter-related Staphylococcus aureus bacteremia.

ribotyping. All isolates showed in vitro susceptibility to oxacillin and vancomycin. The percentages of isolates resistant to penicillin totalled $100 \%$, data not consistent with Dijk et al. (11), who found $72 \%$ isolates resistant to penicillin, in contrast to the present study, there was only methicillin-susceptible $S$. aureus (MSSA). As recorded by Emori and Gaynes (15) Staphylococcus aureus is a major pathogen associated with serious communityacquired and nosocomial disease. Enright et al. (16) observed that the majority of infections acquired in the community and hospitals are caused by methicillin-susceptible Staphylococcus aureus (MSSA). Dijk et al. (11) noted that most attention has been focused on the caracterization of methicillin-resistant $S$. aureus (MRSA), but not much is known about the structure of methicillin-susceptible (MSSA). Enright et al. (16) stated that it is unclear whether some MSSA clones that are circulating within the community or in hospitals have a particular ability to cause serious infections.

In our study, a genetic analysis of MSSA was made using the RiboPrinter Microbial Characterization System, which showed that the $S$. aureus strains were similarly ( $\geq 81 \%)$. Dijk et al. (11) noted that a genetic variation between $S$. aureus isolates involving nonhospitalized individuals is limited, however a cross-transmission could not be excluded, and could occur via the hands of health care workers, handling catheters, hubs, ventilators, stethoscopes, and ultrasound instruments, which could be reservoirs for $S$. aureus. A genetic analysis suggests that most staphylococcal infections arise endogenously. Balaban et al. (2) related that the major risk factor for infection with $S$. aureus in dialysis patients are carriers of S. aureus, in which the nasal area increases the risk of $S$. aureus bacteremia.

\section{CONCLUSION}

This study proned the presence of methicillin-sensitive Staphylococcus aureus (MSSA) in biofilm formation. The biofilms have been shown by scanning electron microscopy to be universally present on central venous catheters either on the outer part of the catheter or the inner lumen. Further studies are necessary to aid in ways to prevent the biofilm formation, and strategies for control.

\section{ACKNOWLEDGMENTS}

The authors are grateful to Doris Elinore Barnes for the English revision, and to the Centro de Referência Diagnóstica (CRD) from Núcleo de Atendimento à Comunidade (NAC), and the Faculdade de Ciências Farmacêuticas-UNESP for financial support.

\section{RESUMO}

\section{Biofilmes de Staphylococcus aureus em cateter venoso central em hemodiálise}

As infecções devido a biofilmes bacterianos são comuns em pacientes sob tratamento em hemodiálise. Neste estudo, 16 pacientes ( 7 homens, 9 mulheres, de 22 a 81 anos, média 50 anos de idade), com um total de 25 cateteres de hemodiálise (3 de triplo-lúmen e 22 de duplo-lúmen) de poliuretano inseridos em veia subclávia foram estudados. Os cateteres permaneceram no local de 3 a 91 dias (média de 47 dias). Os cateteres foram removidos devido ao: mau funcionamento (44\%), suspeita de infecção relacionada ao cateter $(20 \%)$, viabilidade de um acesso permanente (16\%), remoção acidental (12\%), sinais e sintomas de infecção no local da inserção do cateter (4\%) e contaminação exógena $(4 \%)$. Culturas positivas de ponta foram observadas em sete cateteres (28\%), concomitantemente com três culturas positivas de sangue. Das culturas de sangue foram identificados Staphylococcus aureus (12\%) e de uma das conexões foi isolado S. aureus. Biofilmes foram observados sobre todas as pontas de cateteres. Os $S$. aureus isolados do sangue e cateter (ponta e conexão) eram resistentes a pencilina e sensíveis a azitromicina, ciprofloxacina, clindamicina, cloranfenicol, gentamicina, oxacilina, rifampicina, sulfametoxazole, tetraciclina e vancomicina. As cepas de $S$. aureus isoladas de sangue, ponta de cateter e conexão foram consideradas idênticas devido à coincidência do perfil de sensibilidade. E similaridade genética, avaliada por meio de ribotipagem.

Palavras-chave: biofilme, cateter em hemodiálise, cateter venoso central, infecções relacionadas ao cateter 


\section{REFERENCES}

1. Almirall, J.; Gonzalez, J.; Rello, J.; Campistol, J.M.; Montoliu, J.; Bellacasa, J.P.; Revert, L.; Gatell, J.M. Infection of haemodialysis catheter: incidence and mechanisms. Am. J. Nephrol., 9, 454-459, 1989.

2. Balaban, N.; Gov, Y.; Bittler, A.; Boelaert, R. Prevention of Staphylococcus aureus biofilm on dialysis catheters and adherence to human cells. Kidney Int., 63, 340-345, 2003.

3. Bauer, A.W.; Kirby, W.M.M.; Sherris, J.C.; Turk, M. Antibiotic susceptibility testing by a standardized single disk method. Am. J. Clin. Pathol., 45, 493-496, 1966.

4. Butterly, D.W., Schwab, S.J. Catheter acess for hemodialysis: an overview. Seminars in Dialysis, 14, 411-415, 2001.

5. Bruce, L. Automated system rapidly identifies and characterizes microorganisms in food. Food Technol., 50, 77-81, 1996.

6. Cercenado, E.; Ena, J.; Rodriguez-Creixems, M.; Romero, I.; Bouza, E.A conservative procedure for the diagnosis of catheter related infections. Arch. Intern. Med., 150, 1417-1420, 1989.

7. Cleri, D.J.; Corrado, M.I.; Seligman, S.J. Quantitative culture of intravenous catheters and other intravascular inserts. J. Infect. Dis., 141, 781-786, 1980.

8. Costerton, J.W.; Irvin, R.T.; Cheng, K.J. The bacterial glycocalyx in nature and disease. Апnи. Rev. Microbial., 35, 299-324, 1981.

9. Costerton, J.W.; Stewart, P.S.; Greenberg, E.P. Bacterial biofilms: a common cause of persistent infections. Science, 284, 1318-1322, 1999.

10. Cunningham, R.; Cheesbrough, J. Comparative activity of glycopeptide antibiotics against coagulase negative staphylococci embedded in a fibrin clots. J. Antimicrob. Chemother, 30, 321-326, 1992.

11. Dijk, V.Y.; Wielders, C.L.C.; Fluit, A.C.; Paauwn, A.; Diepersloot, R.J.A.; Mascini, E.M. Genotyping of clinical methicillin-susceptible Staphylococcus aureus isolates in a Dutch teaching hospital. J. Clin. Microbiol., 40, 663-665, 2002.

12. Dobbins, B.M.; Kite, P.; Wilcox, M.H. Diagnosis of central venous catheter related sepsis-a critical look inside. J. Clin. Pathol., 52, 165-172, 1999.

13. Donlan, R.M.; Costerton, J.W. Biofilms: survival mechanisms of clinically relevant microorganisms. Clin. Microbiol., 15, 167-193, 2002.

14. Donlan, R.M.; Murga, R.; Bell, M.; Toscano, C.M.; Carr, J.H.; Novicki, T.J.; Zuckerman, C.; Corey, L.C.; Miller, J.M. Protocol for detection of biofilms on needleless connectors attached to central venous catheters. J. Clin. Microbiol., 39, 750-753, 2001.

15. Emori, T.G.; Gaynes, R.P. An overview of nosocomial infections, including the role of the microbiology laboratory. Clin. Microbiol. Rev., 6, 428-442, 1993.

16. Enright, M.; Day, N.P.J.; Davies, C.E.; Peacock, S.J.; Spratt, B.G. Multilocus sequence typing for characterization of methicillinresistant and methicillin-susceptible clones of Stahylococcus aureus. J. Clin. Microbiol., 38, 1008-1015, 2000.

17. Hollis, R.J.; Bruce, J.L.; Fritschel, S.J.; Pfaller, M.A. Comparative evaluation of an automated ribotyping instrument versus pulsedfield gel electrophoresis for epidemiological investigation of clinical isolates of bacteria. Diag. Microbiol. Infect. Dis., 34, 263-268, 1999.

18. Hung, K.Y.; Tsai, T.J.; Yen, T.S. Infection associated with doublelumen catheterization for temporary haemodialysis: experience of 168 cases. Nephrol. Dial. Transplant., 10, 247-251, 1995.

19. Kite, P.; Dobbins, B.M.; Wilcox, M.H.; Fawley, W.N.; Kindon, A.J.L.; Thomas, D.; Tighe, M.J.; McMahon, M.J. Evaluation of a novel endoluminal brush method for in situ diagnosis of catheter related sepsis. J. Clin. Pathol., 50, 278-282, 1997.

20. Kairaitis, L.K.; Gottlieb, T.; Outcome and complications of temporary haemodialysis catheters. Nephrol. Dial. Transplant., 14, 1710-1714, 1999.

21. Kristinsson, K.G.; Burnett, I.A.; Spencer, R.C. Evaluation of three methods for culturing long intravascular catheters. J. Hosp. Infect., 14, 183-191, 1989.
22. Landman, D.; Bratu, S.; Flores, C.; Sathe, S.; Maccario, E.; Ravishankar, J.; Quale, J. Molecular epidemiology of oxacillinresistant Staphylococcus aureus in Brooklyn, New York. Eur. J. Clin. Microbiol. Infect. Dis., 22, 58-61, 2003.

23. Liñares, J.; Sitges-Serra, A.; Garau, J.; Perez, J.L.; Martín, R. Pathogenesis of catheter sepsis: a prospective study with quantitative and semiquantitative cultures of catheter hub and segments. J. Clin. Microbiol., 21, 357-360, 1985.

24. Mah, T.C.; O'Toole, G.A. Mechanisms of biofilm resistance to antiomicrobial agents. Trends Microbiol., 9, 34-39, 2001.

25. Maki, D.G.; Stolz, S.M.; Wheeler, S.; Mermel, L.A. Prevention of central venous catheter-related bloodstream infection by use of an antiseptic-impregnated catheter; a randomized, controlled trial. Am. Intern. Med., 127, 257-266, 1997.

26. Maki, D.G.; Weise, C.E.; Sarafin, H.W. A semiquantitative culture method for identifying intravenous-catheter-related infections. $N$. Engl. Med., 296, 1305-1309, 1977.

27. Marrie, T.J.; Costerton, J.W. Scanning and transmission electron microscopy of in situ bacteria colonization of intravascular and intraarterial catheters. J. Clin. Microbiol., 19, 687-693, 1984.

28. Marrie, T.J.; Nelligan, J.; Costerton, J.W. A scanning and transmission electron microscopic study of an infected endocardial pacemaker lead. Circulation, 66, 1339-1341, 1982.

29. Marr, K.A.; Kong, L.; Fowler, V.G.; Gopal, A.; Sexton, D.J.; Conlon, P.J.; Corey, G.R. Incidence and outcome of Staphylococcus aureus bacteremia in hemodialysis patients. Kidney Int., 54, 1684-1689, 1998.

30. Murray, P.R.; Baron, E.J.; Jorgensen, J.H.; Pfaller, M.A.; Yolken, R.H. Manual of clinical microbiology. $8^{\text {th }}$ ed., ASM, Washington, 2003. 1212p.

31. Nassar, G.M.; Ayus, J.C. Infectious complications of the hemodialysis access. Kidney Int., 60, 1-13, 2001.

32. Nielsen, J.; Ladevoged, S.D.; Kolmos, H.J.J. Dialysis catheter-related septicaemia-focus on Staphylococccus aureus septicaemia. Nephrol. Dial. Transplant., 13, 2847-2852, 1998.

33. Nichols, R.L.; Raad, I.I. Management of bacterial complications in critically ill patients: surgical wound and catheter-related infections. Diagn. Microbiol. Infect. Dis., 33, 121-130, 1999.

34. NCCLS-National Committee for clinical laboratory standards. Performance standards for antimicrobial susceptibility testing: 12th informational supplement, Pennsylvania, 2002, p.M100-S12.

35. Pascual, A. Pathogenesis of catheter-related infections: lessons for new designs. Clin. Microbiol. Infect., 8, 256-264, 2002.

36. Peacock, S.J.; Mandal, S.; Bowler, I.C.J.W. Preventing Staphylococcus aureus infection in the renal unit. Q. J. Med., 95, 405-410, 2002.

37. Pizzolitto, E. L. Contribuição ao estudo in vitro da corrosão induzida por microrganismos sobre liga metálica a base de cobre de uso na odontologia - modelo experimental com as cepas cariogênicas Streptococcus mutans e Streptococcus sobrinus. 1997. 117f. Tese (Doutorado em Biotecnologia) - Instituto de Química, Universidade Estadual Paulista, Araraquara, 1997.

38. Raad, I.I. Intravascular catheter-related infections. Lancet, 351, 893898, 1998.

39. Raad, I.I.; Bodey, G.P. Infectious complications of indwelling vascular catheters. Clin. Infect. Dis., 15, 197-210, 1992.

40. Salzman, M.B.; Isenberg, H.D.; Shapiro, J.F.; Lipsitz, J.; Rubin, G. A prospective study of the catheter-hub as the portal of entry for microorganisms causing catheter-related sepsis in neonates. J. Infect. Dis., 167, 487-490, 1993 .

41. Sherertz, R.J.; Raad, I.I.; Belani, A.; Koo, L.C; Rand, K.H.; Pickett, D.L.; Straub, S.A.; Fauerbach, L.L. Three-year experience with sonicated vascular catheter cultures in a clinical microbiology laboratory. J. Clin. Microbiol., 28, 76-82, 1990.

42. Sitges-Serra, A.; Liñares, J.; Garau, J. Catheter sepsis: the clue is the hub. Surgery, 97, 355-357, 1985. 